\title{
Building a Knowledge Base in Patented Technology and Equipment for Wood Bark Processing and Use in Industries, Agriculture and Social Sphere
}

\author{
Shegelman I. R. ${ }^{1 *}$, Vasilev A. S. ${ }^{2}$, Sukhanov Y. V. ${ }^{2}$, Lukashevich V. M. ${ }^{2}$, Galaktionov O. N. ${ }^{3}$, \\ Kuznetsov A. V. ${ }^{3}$, Krupko A. M. ${ }^{4}$ \\ ${ }^{1}$ Doctor of Technical Sciences, Professor, Cross-Cutting Technology and Economic Security, Petrozavodsk State University (PSU), 33, Lenina pr., \\ Petrozavodsk, Republic of Karelia, Russia \\ ${ }^{2}$ Candidate of Technical Sciences, Associate Professor, Technologies and Organizations of the Forest Complex, Petrozavodsk State University (PSU), \\ 33, Lenina pr., Petrozavodsk, Republic of Karelia, Russia \\ ${ }^{3}$ Doctor of Technical Sciences, Associate Professor, Technologies and Organizations of the Forest Complex, Petrozavodsk State University (PSU), 33 , \\ Lenina pr., Petrozavodsk, Republic of Karelia, Russia \\ ${ }^{4}$ Candidate of Technical Sciences, Associate Professor, Mathematical Analysis, Petrozavodsk State University (PSU), 33, Lenina pr., Petrozavodsk, \\ Republic of Karelia, Russia
}

Received: $15 / 05 / 2020$

Accepted: 21/07/2020

Published: 20/09/2020

\begin{abstract}
For basic operations of the timber industry, numerous technological and technical solutions were patented for the past few years as the results of the intellectual property. The question of building the knowledge bases on technologies and equipment for involvement of the non-wood forest resources into the processing process lacks sufficient attention. Building the knowledge bases in this field resulted from the identified tendency for the development of products from various types of natural raw materials for pharmaceutical, food-manufacturing, cosmetic industries and other areas of the social sphere and economics. Among the various types of natural raw materials, the priority position is occupied by those with wide range of biological effect, including such as wood bark. The development of the knowledge base in the field of wood bark involvement in various social and economic spheres is based on a systematic patent search. Moreover, developers and inventors are increasingly patenting the results of their intellectual activities in the field of promising types of new intellectual property objects for the use of wood bark. This fact indicates that the problems of improving the quality and efficiency of technologies and disintegrating equipment in this area have not been completely resolved. All this necessitates the synthesis and patenting of new market-competitive technologies and equipment for involvement of wood bark in processing and using it in industries, agriculture and in the social sphere. In this regard, the authors conducted research on patent information search, collection and systematization of information. The state and trends of patenting in the field of technologies and equipment for the use of wood bark in industry and in the social sphere were identified, as well as the main patenting goals (effects) of patented intellectual property objects. The article also presents the most noteworthy patents collected during the building of the knowledge base.
\end{abstract}

Keywords: Timber industry, Non-wood forest resources, Intellectual property object, Patent search

\section{Introduction}

In recent years, the results of intellectual activity numerous technological and technical solutions - have been patented for the basic operations of the timber industry. The development of new intellectual property objects necessary in this area is founded on knowledge bases on the state and development trends of improving (created) intellectual property objects. The authors, who build the knowledge bases in various fields [1], believe that when building knowledge bases for various industries of the timber industry, insufficient attention is paid to the field of technologies and equipment for non-wood forest resources. The need to create databases in the field of involvement in the industrial sphere of non-wood forest resources is caused by the identified trends in the development of products using various types of natural raw materials for various sectors of the economy and social sphere. Among these types of natural raw materials, wood bark occupies an important place [2-7].

The purpose of the research is to synthesize the information to build a knowledge base in the field of creating promising technical solutions for technologies and equipment for involving wood bark in the processing and using it in industries, agriculture and in the social sphere. When choosing technologies for such solutions, developers consider the specifics of the areas for the bark use, wood species, and the requirements for the resulting products. Various technologies and equipment are characterized not only by their own specific benefits, but also by their drawbacks, and to effectively

*Corresponding author: Shegelman I. R., Doctor of Technical Sciences, Professor, Cross-cutting technology and economic security, Petrozavodsk State University (PSU), 33, Lenina pr., Petrozavodsk, Republic of Karelia, Russia. E-mail: education.com.ru@gmail.com 
eliminate them, abrupt technological and technical solutions are required. One of the most important factors that confirms the level of such solutions is the patenting by researchers and developers of the results of their intellectual property.

\section{Literature review}

Theoretical and practical aspects of the involvement wood bark in the processing and its use in industries, agriculture and in the social sphere are considered in the works of well-known Russian researchers [6, 8-11]. Levdanskiy in his work [9] deeply examined and developed new methods of complex processing of coniferous and deciduous bark, and justified the effective methods of isolation of tanning substances and anthocyanidin coloring matter from the bark of fir and larch, betulin, suberin and polyphenols from birch bark, and synthesis of betulin derivatives. The author's research is based on the revealed patterns of changes in the chemical composition of the bark of these wood species during activation under the explosive autohydrolysis and the study of the composition of the isolated extracts. The work of Danilov [12] is devoted to the development of technologies and equipment for producing wood-mineral compositions based on bark and fine-dispersed basalt. The author shows that when the content of bark is up to $20 \%$ by weight in a wood-mineral composite, modified bark particles, acting as a damper, effectively work in compression, increase the elasticity of the composite, preventing brittle fracture of the system, which explains the growth of its strength in this range. Further increase in the bark content enhances the ability of the composite to exhibit elastic-plastic properties. The work of Koparev [13] is devoted to the development of technologies and equipment for producing wood-cement composites based on waste from wood yard of the pulp and paper mill.

Many researchers have worked on the development of technologies, equipment, and formulations for processing wood bark to produce organic fertilizers. The effect of organomineral nitrogen fertilizers based on birch bark and fiber on soil properties was studied in the paper by Veprikova and colleagues [14]. The paper of Lugantseva [10] examines the transformation of fertilizer compositions based on wood bark in the soils of the Krasnoyarsk forest-steppe. Ulyanova and Chuprova [15] studied the characteristics of bark mineralization of different types of trees and fertilizer compositions based on it. A number of works are also devoted to the development of technologies and equipment for extracting biologically active substances and valuable chemical products from wood bark. The paper by Badogina and colleagues [16] is devoted to the extraction of biologically active substances from birch bark fiber. Obtaining essential oil from the bark of Siberian fir is studied in the work by Barakov et al. [17]. The work by Ivanova [18] proposes the production of Triflarixynol - new spiroflavonoid from larch bark. Research by Zakharova and collegues [19] studied the possibility of intensifying the isolation of extractive substances from birch bark fiber on exposure to microwave field. Several works are devoted to the development of technologies and equipment for the production of composite slab, construction, furniture and other materials using bark [20-22]. The development of technologies and equipment for the use of wood bark in the production of tanning extracts was also studied [23-25]. Several works studied the development of technologies and equipment for the wood bark use in the production of wood-coal materials [26-29]. In recent years, developments in the production of fuel pellets and briquettes from wood waste, including wood bark, have been intensified
$[11,30]$. The results of these works on the one hand can contribute to the expansion of the volume of procurement of non-traditional wood raw materials, on the other - have not been widely used in production due to insufficient economic efficiency.

Numerous works are devoted to the development of technologies and equipment for the use of wood bark in medicine and perfumes [31-35]. The work of Kondratyuk [36] is devoted to the development of technologies, equipment, and formulations for processing wood bark to obtain food additives. The researchers also proposed the development of technologies and equipment for the use of wood bark in the production of compound feeds and feed additives [37, 38]. The development of technologies and equipment for the use of wood bark in the production of coloring matters was examined in several works [9, 39]. Numerous authors devoted their works to the development of technologies and equipment for the use of bark in the production of oil and oil products sorbent, in wastewater treatment, as well as in the treatment of natural and ground water [40-44].

\section{Materials and Methods}

The purpose of this work is to synthesize information to build a knowledge base in the field of creating promising technical solutions for technologies and equipment for involving wood bark in the processing and using it in industries, agriculture and in the social sphere. The following tasks were defined: (a) to determine areas of effective use of wood bark in industries, agriculture and in the social sphere; (b) to identify areas for patenting technologies and equipment for involving wood bark in the processing and its use; (c) to categorize the main areas of patenting technologies and equipment for involving wood bark in the processing and its use; (d) to categorize effects of patented technologies and equipment for involving wood bark in the processing and its use; and (e) to identify organizations conducting research and patenting of technologies and equipment for involving wood bark in the processing and its use.

To achieve the set goal and tasks, we used a system analysis method based on the results of a patent information search; information was collected and systematized. According to the methodology, the research materials at the first stage of the work were the results of an extended information and analytical search with intensive use of search engines, library collections, materials of dissertation research, as well as information about the content and results of research contained in articles in special trade journals. Special attention was attached to the analysis of research presented in the dissertations of Russian researchers [4, 6, 9-11, 25, 36, 45-]. The second stage of the work involved the extended patent and information search for inventions and utility models patented in the Russian Federation in the area studied by the authors. At the same time, the materials contained in the knowledge bases of the Russian Science Citation Index and the Federal Institute of Industrial Property were extensively used. The analysis helped to identify and categorize areas of patenting technologies and equipment for involving wood bark in the processing and its use in industries, agriculture and in the social sphere. Special attention was paid to the effects (goals) of patented technologies and equipment for wood bark processing. Organizations conducting research and patenting in this field were also identified. 


\section{Results and discussion}

As shown above, the theoretical and practical aspects of involvement wood bark in the processing and its use are considered in the research of well-known Russian researchers. In this section, according to the methodology, we have focused on patenting developments in this area. Krasnoyarsk Research Center of the Siberian Branch (SB) of the RAS (Patent RU2673751) patented a technology that provides for the use of wood bark in the production of phosphorous-potassium fertilizers. It is a method for increasing the agrochemical properties of fertilizers by increasing their water resistance and reducing energy consumption for obtaining fertilizers. In addition, the method allows disposing woodworking waste [47]. Petrozavodsk State University patented the technology to reduce the time spent on fertilizer production by mixing crushed wood bark with farm livestock manure and activated sludge and to increase the productivity of its processing in industrial volumes (Patent RU2647929) [48]. A group of authors patented the technology for the production of complex organomineral fertilizers from wastes of animal husbandry, poultry, wood processing, chemical production (Patent RU2093498) [49]. The technology eliminates the need for long-term exposure of manure for its disinfection, which excludes the need to store waste in dumps that pollute the environment and the cost of creating expensive special storage sites. Chervonobab (Patent RU2496752) patented variants of the method for obtaining organomineral fertilizer of prolonged action (variants) [50]. The method reduces energy and material costs, time, and duration of production of prolonged-action fertilizer with a long storage period and properties that allow it to be used as a means to control insects harmful to plants, trees, and crops. Krasnoyarsk Research Center of the Siberian Branch (SB) of the RAS patented a method for obtaining organomineral fertilizers based on birch bark (Patent RU2629264) [51]. The method improves the agrochemical properties of organomineral fertilizer, simplifies its production and reduces the cost for it, and allows disposing the bark stripping waste. OOO "Gazostroyinvest" patented the foamed carbamide-formaldehyde fertilizer and a method of its production (Patent RU2230719) [52]. This fertilizer is the aerant of the root system in greenhouses and open ground when growing agricultural and decorative crops. Its introduction into the soil stimulates the development of roots and the growth of the aboveground part of plants. Institute of Chemistry and Chemical Technology SB RAS patented the composition for the production of organomineral fertilizer (Patent RU2283294) [53]. The new composition increases the efficiency of fertilizer by increasing the productivity of agricultural plants. The conducted analysis showed that patenting of technologies, equipment, and formulations for wood bark processing to produce organic fertilizers is aimed at achieving the following effects (goals): (a) increasing plant productivity; (b) increasing agrochemical properties of fertilizers; (c) increasing water resistance of fertilizers; (d) reducing the time and energy spent on obtaining fertilizers; (e) reducing the cost of manure exposure for its disinfection; (f) creation of long-acting fertilizers with a long storage period; $(\mathrm{g})$ creation of fertilizers to control insects that are harmful to plants, trees, and crops; and (h) improvement of agrochemical properties of organic fertilizers.

The Department of Problems of Subsoil Development SB RAS patented the substrate for greenhouse and greenhouse farms (Patent RU2115300) [54]. The substrate improves aeration and water-holding capacity of protected ground, as well as optimizes the mode of mineral nutrition of plants due to the increased nutritional value of the substrate. Tropicana products, Inc. (US) patented a group of inventions for a container, a soil mixture, and a method for growing plants (Patent RU2571338) [55]. The patented solution increases the growth rate of plants and roots, as well as the resistance to fungal and microbial infection. OOO "Organika" patented the bark-based biosoil to improve the efficiency of the soil for growing orchids (Patent RU2580159) [56]. The patented biosoil has a balanced composition, which includes fertilizer presented by biohumus as top dressing. The analysis has shown that patenting of substrates and biosoils using bark is aimed at achieving the following effects (goals): (a) improvement of aeration and water-holding capacity of protected soils; (b) optimization of the mineral nutrition regime of plants; (c) increasing the nutritional value of substrates and biosoils; (d) increasing the growth rate of plants and roots; (e) increasing resistance to fungal and microbial infection; and (f) creation of substrates, biosoils with a balanced composition.

A significant number of patents are devoted to the development of technologies and equipment for extracting biologically active substances and valuable chemical products from wood bark. Krasnoyarsk Research Center has patented a method for extracting biologically active compounds from the bark of coniferous species (Patent RU2678683) to create a solution with a wide range of pharmacological action based on extractable substances of the coniferous bark [57]. The achieved effect is to reduce the toxicity of extracting a complex of biologically active compounds. Shcheredin patented a method for producing a mixture of triterpene acids and a mixture of neutral isoprenoids or biologically active substances containing them (Patent RU2385314) [58]. The method increases the output of the final product and reduces the extraction time. Institute of Solid State Chemistry and Mechanochemistry SB RAS patented a method for producing a biologically active sum of triterpene acids (Patent RU2303589) [59]. The achieved effect is to simplify the extraction process and increase the yield and quality of the target extraction product. Krasnoyarsk Research Center patented a method for complex processing of larch bark to obtain valuable chemical products (Patent RU2657427) [60]. This is an environmentally safe and cost-effective way to obtain valuable chemical products - coniferous wax, enterosorbents, polyphenols and organic aerogels - valueadded products based on polyphenols. Krasnoyarsk Research Center patented a method for complex processing of birch bark to obtain valuable chemical products (Patent RU2618892) [61]. The achieved effect is to expand the range of extracted products. Irkutsk Chemistry Institute named after A. E. Favorsky SB RAS patented a method for producing pectin from larch bark (Patent RU2403263) [62], which has a membrane-stabilizing activity and the capacity to restore silver ions, silver nanobiocomposites stabilized with pectin. The method allows obtaining pectin polysaccharides with high yield, membrane-stabilizing activity, and the property of reducing silver ions from salt solutions to nanoscale zerovalence particles. The analysis showed that patents covering the development of technologies and equipment for extracting biologically active substances and valuable chemical products from wood bark are aimed at achieving the following effects (goals): (a) increasing the output of the final extraction product; (b) reducing the time spent for extraction of the final product; (c) simplification of the extraction process; (d) improving the quality of the target extraction product; (e) reducing the toxicity of extracting a complex of biologically active compounds; (f) improving the environmental safety of 
the extraction process; and ( $g$ ) expanding the range of extractable chemical products.

Volga State Technological University patented a composite material based on wood bark (Patent RU182306) [63]. The effect achieved with help of this material is to simplify the manufacturing process. Siberian State Technological University patented a wood-polymer composition (Patent RU2484110) [64]. The achieved effect is an increase in physical and mechanical parameters. OOO "TransPlus" patented a composition (Patent RU2240334) [65], in which birch bark and fiber crushed to $0.1-50 \mathrm{~mm}$ is used as a wood base. The achieved effect is to increase the density, strength, water resistance and resistance against microbes and fungi of products obtained from the proposed composition. Stora Enso Oyj (FI) patented a composite material (Patent RU2592613) with the achieved effect of an increase in hardness, decreased moisture absorption and swelling [66]. OOO "Komi Lesnaya Kompaniya" patented variants of a wood slab and a method of its production (Patent RU2245783), in which the slab consists of a crushed mixture up to a fraction of $40-5000 \mu \mathrm{m}$ of birch bark and a filler mainly made of cellulose fibers [67]. The achieved effect is the simplification of the technological process, reduction in the production cost and expanded product range. Northern (Arctic) Federal University patented bark-based nanocomposite building material (Patent RU2591063) with improved environmental, flammable, sound- and thermal insulation properties, increased physical and mechanical characteristics, resistance to oxidative degradation and biologically active environments [45]. OOO "Verkhne-Saldinskoe Metallurgicheskoe Proizvodstvennoye Obyedineniye" (VSMPO) patented a composite for the production of construction materials (Patent RU2183599) [68]. The achieved effect is an increase in water absorption, strength properties and a decrease in the coefficient of thermal conductivity. ZAO "SNS-Farma" patented a decorative thermal insulation product (Patent RU79832) [69]. The achieved effect is the creation of a new decorative thermal insulation product that has high performance characteristics and provides an expansion of the scope of application. Vladimir University named after A. G. and N. G. Stoletov patented a raw mixture for the manufacture of heat-insulating wood-polymer composite materials (Patent RU2690826) [70]. The achieved effect is to increase the bending strength and reduce the thermal conductivity of the thermal insulation material. Bratsk State Technical University patented a series of patents named "Method for arbolite production." (Patents RU2203242; RU2228307; 2338715) [71-73]. These patents have the achieved effect of increased arbolite strength and water resistance.

The analysis showed that patents covering the development of technologies and equipment for the production of composite slab, construction, furniture and other materials using bark are aimed at achieving the following effects: (a) simplifying of the product manufacturing process; (b) increasing the physical and mechanical parameters of products; (c) increasing the density, strength, hardness and water resistance of products; (d) increasing the resistance against microbes and fungi of products obtained from the proposed composition; (e) reducing the moisture absorption and swelling; (f) simplification of the technological process; (g) cutting the production costs; (h) expanding the range of products; (i) improving the flammable properties; (j) improving the sound- and thermal insulation properties; (k) increasing the physical and mechanical characteristics; (l) providing resistance to oxidative degradation; $(\mathrm{m})$ providing resistance to biologically active media; (n) reducing the thermal conductivity coefficient; (o) improving the bending strength; and (p) reduced thermal conductivity of the thermal insulation material.

Institute of Geology of the Komi Science Centre, Ural Branch, RAS patented a method for obtaining oil and oil product sorbent (Patent RU2638354) [74]. The achieved effect are improved sorption characteristics and expanded raw material base for obtaining the sorbent base. Kazan State University patented a method for protecting soil and ground water from oil and oil products contamination (Patent RU2361041) [75]. The method provides for creation a barrier against downward migration of hydrophobic pollutants in soils. Bratsk State University patented a raw mixture using bark for the production of organomineral sorbent (Patent RU2440846) [76]. The analysis showed that patents covering the development of technologies and equipment for the use of bark in the production of oil and oil product sorbent, soil protection from contamination are aimed at achieving the following effects: (a) improvement of sorption characteristics of sorbents; (b) expansion of the raw material base for obtaining the sorbent base; and (c) prevention of migration of hydrophobic pollutants in soils.

As part of the development of technologies and equipment for production of bark-based cement-wood, concrete-wood materials, a patent of Novosibirsk State Agrarian University can be highlighted - a method of preparing the wood bark filler for concrete (Patent RU2374196) [77]. The method provides for increased strength of concrete. The Northern (Arctic) Federal University patented a bark-based nanocomposition building material (Patent RU2591063) [45]. The achieved effect is to improve flammable, sound- and thermal insulation properties, increase physical and mechanical characteristics, resistance to oxidative degradation and biologically active media. Among the patents aimed at development of technologies and equipment for the use of wood bark in the production of tanning extracts, a patent of the Institute of Chemistry and Chemical Technology SB RAS can be distinguished (Patent RU2352350) [78]. This patent is aimed to simplify the technology by operation without preliminary division of the birch bark and fiber, and to expand the range of forest chemical products obtained. Siberian State Technological University patented a method for producing tanning extract from larch bark (Patent RU2122033), aimed to obtain a high-quality tanning agent [79]. As part of the development of technologies and equipment for using wood bark in the production of coloring matter, a patent by Levdanskiy et al. can be distinguished (Patent RU2137821), which aims at increasing the degree of extraction of extractive substances of fir bark for obtaining food dyes [80]. NorthEastern Federal University patented a method for producing natural coloring matter from larch bark (Patent RU2585193) [81]. The achieved effect is to obtain an environmentally safe and sustainable dye from natural raw materials without using chemical reagents, while preserving the biologically active substances with minimal energy consumption. As part of the development of technologies and equipment for the production of cosmetics using wood bark, a patent of the Siberian State Technological University for a cosmetic product can be highlighted (Patent RU2252017) [82]. The achieved effects include healing of small abrasions, scratches, pimples and blackheads, anti-inflammatory effect, and anti-oxidative effect when massaging the body. As the development of technologies for the production of bark-based drugs for the prevention and treatment of diseases of farm animals, OOO "Agroveyt" patented drug "Raido" (Patent RU2699723) for the prevention 
and treatment of mastitis in cows. Its main feature is its plant basis [83].

As part of the development of technologies and equipment for the use of wood bark in the production of bricks, a patent of the Perm National Research Polytechnic University can be distinguished - raw mixture for the production of ceramic bricks (Patent RU2568453) [84]. The achieved effect is the production of ceramic products that meet the requirements of GOST 530-2012, expansion of the raw material base, utilization of bark and wood waste and recovered stock. As part of the development of technologies and equipment for the use of wood bark in the production of antiseptics, a patent of the Voronezh State Forestry University for a composition for impregnating railway sleepers can be distinguished (Patent RU2690633) [85]. The achieved effect is to improve the quality of wood impregnation. As part of the development of technologies and equipment for the use of wood bark in the production of smoking liquid, a patent of the Kaliningrad Technical University can be highlighted (Patent RU2156071) [86]. The method provides for the expansion of functional capabilities by using bark as a dye, flavor additive, antioxidant and antibacterial agent. As part of the development of technologies and equipment for the use of wood bark in the production of compound feeds and feed additives, a patent of the Krasnoyarsk State Technological Academy can be distinguished (Patent RU2093041) [87]. The achieved effects include an increase in protein content by $9.5 \%$, the use of nonrecyclable waste and post-extraction residue of Siberian larch bark. As part of the development of technologies and equipment for obtaining compost using bark, which is used for recultivation of land disturbed by industrial enterprises, as well as for cultivation of raw soils in agriculture and forestry, a patent of AOOT "LUKoil-Permnefteorgsintez" can be distinguished (Patent RU2044434) [88]. The achieved effect is to improve the sanitary and environmental properties of the substrate by changing compost formulations. Bayer CropScience AG (DE) patented a method for using bark in the production of granulate for insect control (Patent RU2277331) aimed at an increase in the preparation activity [89]. OOO "Fitolon-Nauka" as a part of the development of technologies and equipment for the use of wood bark in the production of odor absorbers received a patent (Patent RU2493905) aimed at expanding the range of gas and unpleasant odors absorbers, improving the environmental situation by using waste from the timber processing industry [90]. Research results allowed identifying the main areas of patenting the developments in the field of procurement and use of wood bark and their patenting economic entities and dividing them into fifteen groups:

- Development of technologies, equipment, formulations for processing wood bark to obtain organic fertilizers (Institute of Chemistry and Chemical Technology SB RAS; Krasnoyarsk Scientific Center SB RAS; Petrozavodsk State University; OOO "Organika"; OOO "Gazostroyinvest"; Department of Problems of Subsoil Development SB RAS; Company "Tropicana products, Inc." (US));

- Development of technologies and formulations for obtaining substrates for greenhouses, tree nurseries (Department of Problems of Subsoil Development SB RAS; Company “Tropicana products, Inc.” (US));

- Development of technologies and equipment for extracting biologically active substances and valuable chemical products from wood bark (Institute of Solid State Chemistry and Mechanochemistry SB RAS; Krasnoyarsk
Research Center SB RAS; Irkutsk Institute of Chemistry named after A. E. Favorsky SB RAS);

- Development of technologies and equipment for the production of composite slab, construction, furniture and other materials using bark (Volga State Technological University; Siberian State Technological University; OOO "Transplus"; Stora Enso Oyj (FI); OOO "Komi Lesnaya Kompaniya"; Northern (Arctic) Federal University; OOO "Verkhne-Saldinskoe Metallurgicheskoe Proizvodstvennoye Obyedineniye"; ZAO "SNS-Farma"; Bratsk State Technical University; Vladimir University named after A. G. and N. G. Stoletov).

- Development of technologies and equipment for production of cement-bark and concrete-bark materials (Novosibirsk State Agrarian University, Northern (Arctic) Federal University);

- Development of technologies and equipment for the production and use of tanning extracts (Institute of Chemistry and Chemical Technology SB RAS; Siberian State Technological University);

- Development of technologies and equipment for the production of bark-based drugs for the prevention and treatment of farm animal diseases (OOO "Agroveyt");

- Development of technologies and equipment for the use of wood bark in the production of bricks (Perm National Research Polytechnic University);

- Development of technologies and equipment for the use of wood bark in the production of antiseptics (Voronezh State Forestry University);

- Development of technologies and equipment for the use of wood bark in the production of smoking liquid (Kaliningrad Technical University);

- Development of technologies and equipment for the use of wood bark in the production of compound feeds and feed additives (Krasnoyarsk State Technological Academy; Irkutsk Chemistry Institute named after A. E. Favorsky);

- Development of technologies and equipment for obtaining bark-based compost used for recultivation of land disturbed by industrial enterprises, as well as for cultivation of raw soils in agriculture and forestry (AOOT "LUKoil-Permnefteorgsintez");

- Development of technologies and equipment for using wood bark in obtaining sorbent of oil and oil products, in wastewater treatment, as well as in the treatment of natural and ground water (Bratsk State University, Institute of Geology of Komi Science Centre, Ural Branch; Kazan State University);

- Development of technologies and equipment for the use of bark in the production of granulate for insect control (Bayer CropScience AG (DE);

- Development of technologies and equipment for the use of wood bark for the production of odor absorbers (OOO "Fitolon-Nauka").

There is a tendency towards expanding the patenting of inventions and utility models by many universities, research organizations and enterprises in the field of involvement wood bark in the processing and its use in industries, agriculture and in the social sphere. Apparently, the use of bark in these areas will grow, as well as the need for effective technologies and equipment for its involvement in processing and use.

\section{Conclusions}

In recent years, the results of intellectual activity numerous technological and technical solutions - have been patented for the basic operations of the timber industry. The 
development of new intellectual property objects necessary in this area is based on knowledge bases on the state and development trends of improving (created) intellectual property objects. The authors, who build the knowledge bases in various fields, believe that when building knowledge bases for various industries of the timber industry, insufficient attention is paid to the field of technologies and equipment for non-wood forest resources. The need to create databases in the field of involvement in the industrial sphere of non-wood forest resources is caused by the identified trends in the development of products using various types of natural raw materials for various sectors of the economy and social sphere. Among these types of natural raw materials, wood bark occupies an important place. The analysis showed that there is a significant amount of serious research in the field of technologies and equipment for processing involving wood bark. However, despite the established research and technological groundwork, many of these studies are still under development and are often not implemented due to the lack of industrial partners and insufficient attention of researchers and developers to patenting the results of their intellectual activity, the lack of competitive patented intellectual property objects. The analysis revealed the effects (goals) of patented technologies and equipment for the involvement wood bark in the processing and its use. For example, in the development of technologies and equipment for extracting biologically active substances and valuable chemical products from wood bark, patenting was aimed at achieving the following effects: increasing the output of the final extraction product; reducing the extraction time of the final product; simplifying the extraction process; improving the quality of the target extraction product; reducing the toxicity of extracting a complex of biologically active compounds; improving the environmental safety of the extraction process; expanding the range of extracted chemical products. Areas of patenting technologies and equipment for involving wood bark in the processing and its use in industries, agriculture and social sphere were categorized into 15 groups. Economic entities conducting research and patenting in the field under study were identified. It is worth noting that universities prevail among them in Russia. Companies that are engaged in patenting in this area include: AOOT "LUKoilPermnefteorgsintez", ZAO "SNS-Farma", OOO "Agroveyt", OOO "Verkhne-Saldinskoe Metallurgicheskoe Proizvodstvennoye Obyedineniye", OOO "Komi Lesnaya Kompaniya", OOO "Organika"; OOO "Gazostroyinvest", OOO "Transplus"; OOO "Fitolon-Nauka", Bayer CropScience AG (DE), Stora Enso Oyj (FI), "Tropicana products, Inc." (US). The knowledge base built during the research can be successfully used when selecting analogues and prototypes for the synthesis of new patentable solutions.

\section{References}

1. Shegelman IR, Shtykov AS, Vasilev AS, Galaktionov ON, Kuznetsov AV, Sukhanov YV. Systematic Patent-Information Search as a Basis for Synthesis of New Objects of Intellectual Property: Methodology and Findings. International Journal of innovative Technology and Exploring Engineering (IJITEE). 2019;8(8):395-403.

2. Velichko NA, Ushanova VM. (1994). Feed additives from fir bark. Lesnaya Promyshlennost. 1994;5-6:20.

3. Ivkina TM, Levin ED. Oil Capacity and Calorific Value of Pine and Fir Bark Used for Oil Spill Clean-Up in Water Reservoirs. Izv. Vyssh. Uchebn. Zaved., Lesn. Zh. 1986;6:83-6.

4. Ryazanova TV. Complex processing of coniferous trees bark with obtaining tannic extracts with desired properties. 1999.
5. Stepen RA, Ushanova VM, Ushanov, SV. Modeling the content of essential oil in tree greenery and bark of abies sibirica of various age. Sistemy. Metody. Tekhnologii. 2017;3(35):127-130.

6. Ushanova VM. Complex processing of wood greens and bark of Siberian fir to obtain products with biological activity [Doctoral dissertation; Siberian State Technological University]. Krasnoyarsk. 2012.

7. Douce DS, Clench MR, Cooke M, Wang J. Evidence for the adsorption of nitrated polycyclic aromatic hydrocarbons by tree bark. Journal of Chromatography A. 1997 Oct 31;786(2):275-83.

8. Kononov OD. Agro-chemical and ecological-ameliorative aspects of application of non-traditional organic fertilizers for increasing the fertility of drained soils of Northern- and Central Taiga subzones of Non-Black Soil Zone [Doctoral dissertation]. Arkhangelsk. 2000.

9. Levdanskiy VA. Complex processing of timber bark using the processes of extraction and explosive autohydrolysis [Doctoral dissertation]. Krasnoyarsk. 2006.

10. Lugantseva MV. Transformation of fertilizing compositions based on wood bark in the soils of the Krasnoyarsk forest-steppe [Doctoral dissertation; Krasnoyarsk State Agrarian University]. Krasnoyarsk. 2010.

11. Muller OD. Improving the technologies for wood pellets production [Doctoral dissertation; Northern (Arctic) Federal University named after M. V. Lomonosov]. Arkhangelsk. 2015.

12. Danilov VE. Colloid-chemical aspects of obtaining the timbermineral compositions based on the bark and fine-dispersed basalt [Doctoral dissertation; Belgorod State Technological University named after V. G. Shukhov]. Belgorod. 2018.

13. Koparev VS. Substantiating of technological solutions for recycling the wastes from wood yard of pulp and paper mill into the building materials [Doctoral dissertation; Petrozavodsk State University]. Petrozavodsk. 2014.

14. Veprikova EV, Kuznetsova SA, Chesnokov NV, Ulyanova OA Influence of organomineral fertilizers based on the birch bark and inner birch bark on the soil properties. Journal of Siberian Federal University. Chemistry. 2016 Jul 1;9(3):258

15. Ulyanova OA, Chuprova VV. Mineralization of bark from different tree species and bark-based fertilizer compositions. Agrokhimiya. 2015;2:33-45

16. Badogina AI, Tretyakov SI, Kutakova NA, Koptelova EN. Extraction of biologically active substances from the birch bark fiber. Khimiya Rastitelnogo Syrya. 2015;2:135-140.

17. Barakov, T. V., Golikov, A. A., \& Usoltseva, L. P. (1997) Obtaining essential oil from the Siberian fir bark. In Extractive substances of the timber species from the Central Siberia. Krasnoyarsk. 1997; 77-84.

18. Ivanova SZ, Fedorova TE, Ivanova NV, Fedorov SV, Babkin VA. Triflarixynol - a new spiroflavonoid from larch bark. Khimiya Rastitelnogo Syrya. 2006;1:37-40.

19. Zakharova AI, Tretyakov SI, Kutakova NA, Koptelova EN Obtaining the extracting substances from birch bark fiber on exposure to microwave field. Lesnoy Zhurnal. 2015;4(346):148155.

20. Rudenko BD. Properties of slabs from wood bark and secondary polyethylene. Derevoobrabatyvayushchaya Promyshlennost. 2010;1:7-8.

21. Sudakova IG, Garyntseva NV, Kuznetsov BN. Production of wood slab material using the binding agent based on birch-bark suberin. Khimiya Rastitelnogo Syrya. 2011;3:65-68.

22. Sudakova IG, Garyntseva NV, Ivanov IP, Kuznetsov BN. Isolation and application of suberin from outer birch-bark. JOURNAL OF SIBERIAN FEDERAL UNIVERSITYCHEMISTRY. 2012 Jan 1;5(2):168-77.

23. Kemppainen K, Siika-aho M, Pattathil S, Giovando S, Kruus K. Spruce bark as an industrial source of condensed tannins and noncellulosic sugars. Industrial Crops and Products. 2014 Jan 1;52:158-68.

24. Eremenko ON, Mishura PV, Ryazanova TV, Tok MV. Improving the production of tanning extracts from conifer bark using the alkaline extractants. Vestnik KrasGAU. 2015;2(101):90-95. 
25. Tyulkova YuA. Pine bark processing with obtaining tanning extracts [Doctoral dissertation; Sibirian State Technological University]. Krasnoyarsk. 2013.

26. Ivanov IP, Sudakova IG, Ivanchenko NM, Kuznetsov BN. Study of the properties of active carbons from granulated larch bark. Khimiya Rastitelnogo Syrya. 2011;1:81-86.

27. Kuznetsov BN, Golovin YuG, Golovina VV, Eremina AO, Levdanskiy VA. Production of carbonic adsorbents from the products of extraction processing of Siberian larch bark. Khimiya Rastitelnogo Syrya. 2002;2:57-61.

28. Rudkovsky AV, Shchipko ML, Golovina VV, Eremina AO, Levdanskiy VA, Polezhaeva NI, Kuznetsov BN. Obtaining activated carbon from fir bark and residues of its extraction processing. Khimiya Rastitelnogo Syrya. 2003;1: 97-100.

29. Shchukina AV, Epifantseva NS, Simkin Y. Ya., and Stepen', RA, Bark of floated Siberian fir: A raw material for charcoal production. Khim. Rastit. Syr'ya. 2006(2):61-2.

30. Ponomareva NG. Improving the technology for production of fuel pellets from wood bark [Doctoral dissertation; Northern (Arctic) Federal University named after M. V. Lomonosov]. Arkhangelsk. 2017.

31. Annegowda HV, Gooi TS, Awang SH, Alias NA, Mordi MN. Evaluation of Analgesic and Antioxidant Potency of Various. International journal of Pharmacology. 2012;8(3):198-203.

32. Boakye PA, Brierley SM, Pasilis SP, Balemba OB. Garcinia buchananii bark extract is an effective anti-diarrheal remedy for lactose-induced diarrhea. Journal of ethnopharmacology. 2012 Jul 13;142(2):539-47.

33. Zhang L, Chen J, Wang Y, Wu D, Xu M. Phenolic extracts from Acacia mangium bark and their antioxidant activities. Molecules. 2010 May;15(5):3567-77.

34. Kuznetsova SA, Kuznetsov BN, Levdanskiy VA. Synthesis and properties of enterosorbents from a bass of a birch bark. Khimia rastitelnogo syrya. 2004;2:25-9.

35. Makarova OG, Turetskova VF. Research of release kinetics of phenolic acids from medicinal forms on the basis of aspen bark dry extract. Fundamentalnye Issledovaniya. 2013;4-5:1164-1168.

36. Kondratyuk TA. Obtaining and evaluation of consumer properties of food products from Siberian larch bark [Doctoral dissertation; Kemerevo Technological Food Industry Institute]. Kemerevo. 2009.

37. Simonov GA. Birch bark in diets for egg type chicks. Ptitsevodstvo. 2011;1:41-42.

38. Simonov GA, Zoteev VS, Simonov AG. Birch bark in the diet of broiler chicken increases their performance. Effektivnoe Zhivotnovodstvo. 2015;3-4(113):42-43.

39. Levdanskiy VA, Butylkina AI, Kuznetsov BN. Optimization of the process of obtaining the anthocyanidin coloring matter from fir and larch bark. Khimiya Rastitelnogo Syrya. 2008;4:51-54.

40. Cutillas-Barreiro L, Ansias-Manso L, Fernández-Calviño D, Arias-Estévez M, Nóvoa-Muñoz JC, Fernández-Sanjurjo MJ, Álvarez-Rodríguez E, Núñez-Delgado A. Pine bark as bioadsorbent for $\mathrm{Cd}, \mathrm{Cu}, \mathrm{Ni}, \mathrm{Pb}$ and $\mathrm{Zn}$ : batch-type and stirred flow chamber experiments. Journal of environmental management. 2014 Nov 1;144:258-64.

41. Salem NM, Awwad AM. Biosorption of $\mathrm{Ni}$ (II) from electroplating wastewater by modified (Eriobotrya japonica) loquat bark. Journal of Saudi Chemical Society. 2014 Nov $1 ; 18(5): 379-86$

42. Veprikova EV, Kuznetsova SA, Chesnokov NV. Water purification from copper, zink and lead with sorbents from birch bark fiber. Zhurnal Sibirskogo Federalnogo Universiteta, series "Khimiya". 2015;8(2):202-210.

43. Kuznetsov BN, Chesnokov NV, Ivanov IP, Veprikova EV, Ivanchenko NM. Methods for obtaining the porous materials from lignin and timber bark (review). Zhurnal Sibirskogo Federalnogo Universiteta, series "Khimiya". 2015;8(2);232-255.

44. Semenovich AV, Loskutov SR. The regularity of the metal cation sorption by the modified bark of siberian coniferous tree species. Vestnik KrasGAU. 2015;1(100):197-202.

45. Danilov VE, Ayzenshtadt AM, Tutygin AS, Frolova MA, Makhova TA. Russian Patent no. 2591063 "Wood bark-based nanocomposite structural material.” 2016.
46. Ilyushenko DA. Development of technology for production of briquettes from bark-stripping wastes [Doctoral dissertation; Saint-Petersburg State Forest Technical University]. St. Petersburg. 2012.

47. Veprikova EV, Belash MYu, Kuznetsov BN, Chesnokov NV Russian Patent no. 2673751 "Method of obtaining phosphatepotassium fertilizers based on wood bark." 2018.

48. Gavrilov TA. Russian Patent no. 2647929 "Method for processing tree bark." 2018

49. Kolesnichenko EN, Ilyukhin VS, Lysenko NP. Russian Patent no. 2093498 "Method of manufacturing complex organomineral fertilizer." 1997.

50. Chervonobab NL. Russian Patent no. 2496752 "Method of producing organomineral fertiliser with prolonged action (versions)." 2015.

51. Veprikova EV, Kuznetsova SA, Kuznetsov BN, Chesnokov NV. Russian Patent no. 2629264 "Method of obtaining organomineral fertilisers based on birch bark." 2017.

52. Melkozerov VM, Nagorny LD, Oleynik VV, Makhnovetsky AB, Maksimenko VP, Mazhaysky YuA, Deev SYu, Borodychev VV, Adyaev SB, Chaplanova MP. Russian Patent no. 2230719 "Foamed carbamide-formaldehyde fertilizer and method for its preparing." 2004.

53. Ulyanova OA, Lyukshina IV, Chuprova VV, Kulebakin VG Russian Patent no. 2283294 "Composition for manufacturing organomineral fertilizer." 2006.

54. Ulyanova OA, Kozintseva NI, Moskalev AK. Russian Patent no. 2115300 "Substrate for plant culturing in protected soil." 1998.

55. Keithly JH, inventor; Tropicana Products Inc, assignee. Container, Soil Blend, and Method of Growing Plants. United States patent application US 13/724,689. 2013 Jun 27.

56. Popova NV. Russian Patent no. 2580159 "Bioground for orchids." 2016.

57. Loskutov SR, Semenovich AV. Permyakova GV. Russian Patent no. 2678683 "Method of extraction of biologically active compounds from the bark of coniferous wood species." 2019.

58. Shcheredin VF, Klimov VP. Russian Patent no. 2385314 "Method of preparing mixture of triterpene acids and mixture of neutral isoprenoids or biologically active substances containing said compounds." 2010.

59. Korolev KG, Lomovskiy OI. Russian Patent no. 2303589 "Method for production of biologically active sum of triterpene acids." 2007.

60. Levdanskiy VA, Sudakova IG, Levdanskiy AV, Skvortsova GP, Kuznetsov BN, Mikova NM. Russian Patent no. 2657427 "Method of the larch bark complex processing." 2018.

61. Kuznetsov BN, Sudakova IG, Kuznetsova SA, Grishechko LI, Skvortsova GP, Veprikova EV, Levdanskiy VA. Russian Patent no. 2618892 "Method for complex processing of birch bark." 2017.

62. Babkin VA, Ivanova NV, Trofimova NN, Eskova LA, Salyaev RK, Nurminskiy VN, Korzun AM, Feoktistova LP, Sapozhnikov AN, Likhoshvay EV, Arsentyev KYu. Russian patent no. 2403263 "Method of obtaining pectine from larch bark having membrane stabilising activity and capacity to reduce silver ions of silver nanobiocomposite stabilised with pectine." 2010.

63. Mikryukova EV, Sedykh MA, Akhmedov SR. Russian Patent no. 182306 "Wood bark composite material." 2018.

64. Ushanova VM, Krivorotova AI. Russian Patent no. 2484110 "Wood and polymer composition." 2013.

65. Sternin YuI, Yurchenko IV, Zagoruyko AD. Russian Patent no. 2240334 "Wood-based composition." V2004.

66. Pynnönen J, Myyryläinen M, Mayes D, Silen J. Russian Patent no. 2592613 "Composite material." 2016.

67. Pressman GV, Nikolaev VV, Andreyakhin SV, Bekker IV, Semochkin YuA, Shilkov NA. Russian Patent no. 2245783 "Wood-based panel and the method of its production (alternatives)." 2005

68. Lipunov IN, Kudryavskiy YuP, Alikin VI, Tetyukhin VV, Yupatov AA. Russian Patent no. 2183599 "Composition compound for production of building materials." 2002.

69. Sternin YuI, Yurchenko IV, Moskalev EV. Russian Patent no. 79832 "Decorative heat-insulating product." 2009. 
70. Kolosova AS, Sokolskaya MK, Pikalov ES, Selivanov OG. Russian Patent no. 2690826 "Crude mixture for production of heat-insulating wood-polymer composite materials." 2019.

71. Rusina VV, Podvolskaya EN, Tarasova NYu, Bobrova AA, Furina IV. Russian Patent no. 2203242 "Sawdust concrete manufacture process." 2003.

72. Rusina VV, Podvolskaya EN, Tarasova NYu, Bobrova AA, Furina I.V. Russian Patent no. 2228307 "Sawdust concrete manufacture process." 2004.

73. Rusina VV, Podvolskaya EN, Tarasova NYu, Bobrova AA, Furina IV. Russian Patent no. 2338715 "Method of cement wood manufacture.” 2008.

74. Kocheva LS, Karmanov AP, Kochanova AV. Russian Patent no. 2638354 "Method of producing oil and oil product sorbent." 2017.

75. Breus IP, Breus VA, Neklyudov SA. Russian Patent no. 2361041 "Method for protection of grounds and groundwater against contamination with oil and oil products." 2009.

76. Lokhova NA, Lazar VV, Stibunova NS, Starkova AG, Pogodaeva AA, Mamedov KM, Sitdikov IF, Sizova IS. Russian Patent no. 2440846 "Crude mixture for producing organomineral sorbent." 2012.

77. Denisov AS, Khritankov VF, Avramenko VV, Pichugin AP. Russian Patent no. 2374196 "Method of preparing the wood bark filler for concrete." 2009

78. Levdanskiy VA, Levdanskiy AV, Kuznetsov BN. Russian Patent no. 2352350 "Method of birch bark conversion." 2009.

79. Ryazanova TV, Chuprova NA, Eremenko ON. Russian Patent no. 2122033 "Method of isolating tanning extract from bark of larch." 1998.

80. Levdanskiy VA, Polezhaeva NI, Eskin AP, Safronova LV, Kuznetsov BN. Russian Patent no. 2137821 "Method of processing fir bark." 1999.

81. Nikiforova AA, Zhebsaina SM, Gaenkova IV. Russian Patent no. 2585193 "Method of producing natural colouring agent from larch bark." 2016.

82. Ushanova VM, Lebedeva OI, Mulyava VE. Russian Patent no. 2252017 "Cosmetic preparation and method for its obtaining." 2005.

83. Solodovnikova ES, Kolesnik AB, Aminova AL, Rameev TV. Russian Patent no. 2699723 "Preparation 'Raido' for preventing and treating mastitis in cows and a method for production thereof." 2019.

84. Vaysman YaI, Pugin KG, Dyakov MS, Kulikova YuV, Shirinkina ES, Yudin SYu, Kurilo ON, Chumakov AYu, Monchenko SV. Russian Patent no. 2568453 "Raw mix for ceramic brick manufacturing." 2015.

85. Belchinskaya LI, Zhuzhukin KV, Dmitrenkov AI, Novikova LA. Russian Patent no. 2690633 "Composition for impregnating railway sleepers." 2019.

86. Mezenova OI, Kochelaba NYu. Russian Patent no. 2156071 "Smoking liquid preparing method." 2000.

87. Velichko NA, Repyakh SM. Russian Patent no. 2093041 "Method for obtaining feed additive." 1997.

88. Korovkin AS, Vrublevskiy VS, Korovkin VA, Shuverov VM, Shchekoldin NA, Kalinin NF. Russian Patent no. 2044434 "Method for recultivation of disturbed soil." 1995.

89. Noeding G, Nied A, Adams A, Diehlmann H, Wagenbach M. Russian Patent no. 2277331 "Solvent-free water dispersible granulate for cockroach controlling and method for cockroach controlling." 2006.

90. Nekrasova VB. Russian Patent no. 2493905 "Absorber of gases and odor nuisances (versions) and organic mineral fertilisers." 2017. 